Article

\title{
Study on the Possibility of Improving the Environmental Performance of Diesel Engine Using Carbon Nanotubes as a Petroleum Diesel Fuel Additive
}

\author{
Vladimir Markov ${ }^{1}$, Vyacheslav Kamaltdinov ${ }^{2, *(1)}$, Anatoliy Zherdev ${ }^{1}$, Viktor Furman ${ }^{3}$, \\ Bowen Sa ${ }^{1}\left[\right.$ and Vsevolod Neverov ${ }^{1}$ \\ 1 Power Engineering Faculty, Bauman Moscow State Technical University, 5, 2-ya Baumanskaya Str., \\ Moscow 105005, Russia; vladimir.markov58@yandex.ru (V.M.); azherdev@bmstu.ru (A.Z.); \\ bowensa@yandex.ru (B.S.); sevasxp@mail.ru (V.N.) \\ 2 Motor Transport Faculty, South Ural State University, 76, Lenin Ave., Chelyabinsk 454080, Russia \\ 3 Design and Production Enterprise "Dieselautomatika", 109, Chernyshevskogo Str., Saratov 410017, Russia; \\ dizavt@overta.ru \\ * Correspondence: vkamaltdinov@yandex.ru
}

Received: 16 October 2019; Accepted: 13 November 2019; Published: 15 November 2019

check for updates

\begin{abstract}
The relevance of this article is due to the need for improving indicators of exhaust gas toxicity of diesel engines. One of the modern directions of achieving the required environmental performance of diesel engines is the addition of various nanomaterials to petroleum diesel fuel. The aim of the present study was to investigate the possibility of improving the environmental performance of a diesel engine for a generator set using carbon nanotubes as an additive to petroleum diesel fuel in an amount of up to $500 \mathrm{mg} / \mathrm{L}$. Experimental studies were carried out on a D-243 diesel engine operating in a wide range of loads from idle to full load with the addition of 125, 250, and $500 \mathrm{mg} / \mathrm{L}$ of carbon nanotubes in the diesel fuel. The mixing of petroleum diesel fuel with nanotubes was done using an ultrasonic unit. The possibility of improving the environmental performance of the studied diesel engine fueled with carbon nanotube-blended petroleum diesel fuel was examined. Results showed that, in the full-load mode of diesel operation, the addition of $500 \mathrm{mg} / \mathrm{L}$ of carbon nanotubes to diesel fuel enabled the engine to reduce exhaust smoke from $26.0 \%$ to $11.2 \%$ on the Hartridge scale.
\end{abstract}

Keywords: diesel engine; petroleum diesel fuel; carbon nanotubes; exhaust emissions; exhaust smoke

\section{Introduction}

The depletion of fossil fuel resources and the deterioration of environmental-ecological conditions necessitate the use of alternative fuels in internal combustion engines (ICEs) [1-3]. Promising alternative fuels for diesel engines include natural gas, plant biofuels, ethers, and alcohol fuels [4-6].

Recently, with the rapid development of nanotechnology, a number of studies have been conducted on the possibility of adding different nanomaterials to traditional petroleum fuels. These materials have a high diffusion coefficient, a large surface-to-volume ratio, high reactivity, and other special characteristics [7-9]. Adding nanomaterials to liquid petroleum fuel accelerates the mass transfer and thermal transfer processes and increases the reaction activity of the blended fuel. As a result, the quality of the air-fuel mixture formation and combustion process is improved, and the ignition delay period and the combustion duration are reduced. The improved combustion process also enhances emission 
performance. In this regard, the use of nanomaterials as ecological and energy additives to diesel fuel (DF) is very promising for transport energy.

Nanofluids containing nanoparticles and agglomerates of particles (e.g., metals, oxides, carbides, nitrides, or carbon nanotubes (CNTs)) with characteristic size from 0.1 to $100 \mathrm{~nm}$ have been studied in a number of works. These nanoparticles have been added to both petroleum diesel fuel and various biofuels or blended fuels. Heydari-Maleney et al. [10] studied the influence of CNT addition in blended fuels from petroleum DF, biodiesel, and ethanol on the performance and emission characteristics of a single-cylinder diesel engine. The biodiesel was produced from waste vegetable oil through transesterification $[11,12]$. Ethanol at the concentrations of $2 \%, 4 \%$, and $6 \%$ as well as CNTs in the mass fractions of 20,60, and $100 \mathrm{ppm}(1 \mathrm{ppm}=0.0001 \%)$ were added to the blended fuel B2 (98\% DF and $2 \%$ biodiesel). These components were blended in an ultrasonic homogenizer. The diesel engine was tested under full load at three engine speed levels: 1700, 2300, and $2900 \mathrm{rpm}$. The experimental results showed that using the blended fuel with maximum concentrations of ethanol and CNT reduced the carbon monoxide (CO), unburnt hydrocarbon (HC), and soot emissions by $5.47 \%, 31.72 \%$, and $6.96 \%$, respectively, compared to pure DF.

Sadhik Basha and Anand [13] conducted an experimental investigation of a single-cylinder diesel engine running on an emulsion of methyl ether of jatropha oil with the addition of CNTs. This emulsion fuel consisted of $93 \%$ (by volume) methyl ether of jatropha oil, $5 \%$ water, and $2 \%$ surfactants. CNTs were dispersed into the emulsion at the concentrations of 25,50 , and $100 \mathrm{ppm}$.

Balaji and Cheralathan [14] experimentally investigated the performance and emission characteristics of a diesel engine fueled by methyl ether of neem oil mixed with CNTs. The concentrations of CNT in the blended fuels were 100, 200, and 300 ppm.

El-Seesy et al. [15] conducted an experimental study on the effect of adding CNTs to a blended biofuel on diesel engine performance. The blended biofuel $(80 \%$ DF and $20 \%$ methyl ether of jojoba oil) was mixed with CNTs (1-10 $\mu \mathrm{m}$ length, $10-15 \mathrm{~nm}$ diameter) at the concentrations of $10,20,30,40$, and $50 \mathrm{mg} / \mathrm{L}$.

Sadhik Basha and Anand [16] investigated a diesel engine running on different fuels with the addition of CNTs. Experimental tests were carried out on petroleum DF and water-diesel emulsion fuel. The water-diesel emulsion fuel contained $93 \% \mathrm{DF}, 5 \%$ water, and $2 \%$ surfactants (by volume). The CNTs were added to the emulsion fuel in the mass fractions of 25 and $50 \mathrm{ppm}$.

An analysis of published papers shows that the addition of carbon nanotubes in diesel fuels and blended biodiesel fuels could improve engine emission performance. At the same time, the dose of carbon nanotubes in the above-listed works was small and no more than $300 \mathrm{ppm}$. The novelty of this work is that it investigated the possibility of improving the environmental performance of a diesel engine for a generator set with the addition of a significantly larger amount of CNT in petroleum diesel fuel (up to $500 \mathrm{mg} / \mathrm{L}$ ).

\section{Materials and Methods}

In this paper, the operational performance of a diesel engine for a generator set was investigated using carbon nanotubes produced in the People's Republic of China as an additive to petroleum diesel fuel. The present research used TNIM1 CNTs, which are multiwalled carbon nanotubes for industrial purposes (industrial grade multiwalled carbon nanotubes). They are produced by Timesnano (affiliated with Chengdu Organic Chemicals Co. Ltd., Chinese Academy of Sciences) through chemical vapor deposition (CVD).

Timesnano produces carbon nanotubes of various grades [17]. They differ in the type (single-walled and multiwalled carbon nanotubes for industrial or laboratory use), the outer diameter (from 1-2 to $5-15 \mathrm{~nm}$ ), the length (from $0.5-2.0$ to $20-40 \mu \mathrm{m}$ ), and the degree of purity (from $60 \%$ to $98 \%$ or more). TNIM1 CNTs have a favorable compromise between the price and their properties. They are distinguished by a low price (the price is $\$ 83 / \mathrm{kg}$ when ordering more than $10 \mathrm{~kg}$ ). In addition, TNIM1 CNTs have a very short length $(10-30 \mu \mathrm{m})$, which makes it possible to inject fuel containing these 
nanotubes into a cylinder through a conventional diesel injector. At the same time, the small outer diameter (5-15 nm), high purity (more than 95\%), and specific surface area (220-300 $\mathrm{m}^{2} / \mathrm{g}$ ) of these nanotubes increase the diffusion capacity and the reactivity of fuel mixed with them.

CNTs used in other studies had similar dimensions and properties. CNTs studied in [15] had an average length of 1-10 $\mu \mathrm{m}$ and an average diameter of 10-15 $\mathrm{nm}$. In [13], mixed fuel with the addition of CNTs with a diameter of $16 \mathrm{~nm}$ and a specific surface of $672 \mathrm{~m}^{2} / \mathrm{g}$ was investigated. Nanoadditive with an average particle size of $51 \mathrm{~nm}$ and a specific surface area of $32 \mathrm{~m}^{2} / \mathrm{g}$ were studied in [18].

Given the price of TNIM1 CNTs $(\$ 83 / \mathrm{kg})$, the increase in price of mixed fuel with the addition of these CNTs in an amount of $125-500 \mathrm{mg}$ per liter of DF will be $\$ 0.01$ to $\$ 0.04$. Such a slight increase in price of CNT-blended fuel will contribute to the large-scale practical application of these CNTs in vehicles. Moreover, when the order is more than $100 \mathrm{~kg}$, the price of TNIM1 CNTs will be even lower.

\section{Experimental Setup and Procedure}

To evaluate the parameters and characteristics of a diesel engine running on petroleum DF with the addition of CNTs, experimental studies were conducted on a test bench. The main element of this platform was a four-cylinder, four-stroke D-243 compression ignition engine without turbocharging. This engine was manufactured by Minsk Motor Plant (Minsk, Republic of Belarus) (Figure 1a). While creating this test bench, a diesel generator set produced by Minsk Motor Plant (Figure 1b) that produces alternating current (AC) was used. In this generator set, the abovementioned D-243 diesel engine was used as the primary engine. An ECO-ECP electric AC generator produced by RINA (Genova, Italy) was used. In experimental studies, the electric power generated by the generator was consumed by three fan heaters. The maximum power of each fan heater was $12 \mathrm{~kW}$ (these fan heaters can also operate under a power load of $6 \mathrm{~kW}$ ). The investigated D-243 diesel engine had a rated power of $N_{e}=36 \mathrm{~kW}$ at $1500 \mathrm{rpm}$. The main parameters of the studied diesel engine are listed in Table 1. Figure 2 shows the geometry of the diesel combustion chamber with the injector location scheme and the orientation of the fuel sprays in the combustion chamber.

In the experiment, we measured the amount of harmful pollutants and soot in exhaust gases. The smoke opacity of exhaust gas was measured with an Infracar D1.01 opacimeter produced by Zapadpribor (Moscow, Russia) (Figure 3a). The concentrations of regulated pollutants in the exhaust gases (nitrogen oxides $\left(\mathrm{NO}_{\mathrm{x}}\right), \mathrm{CO}$, and unburned light $\mathrm{HC}$ ) were determined by an Infracar 5M-3.01 gas analyzer from Zapadpribor (Figure $3 b$ ). The measurement range and accuracy of each parameter are given in Table 2.

In this study, TNIMI1 CNTs by Timesnano were added to petroleum diesel fuel of brand "L" (Russian GOST 305-82). Moreover, the dose level of CNTs in the tested diesel fuel ranged from 0 (pure DF) up to $500 \mathrm{mg} / \mathrm{L}$.

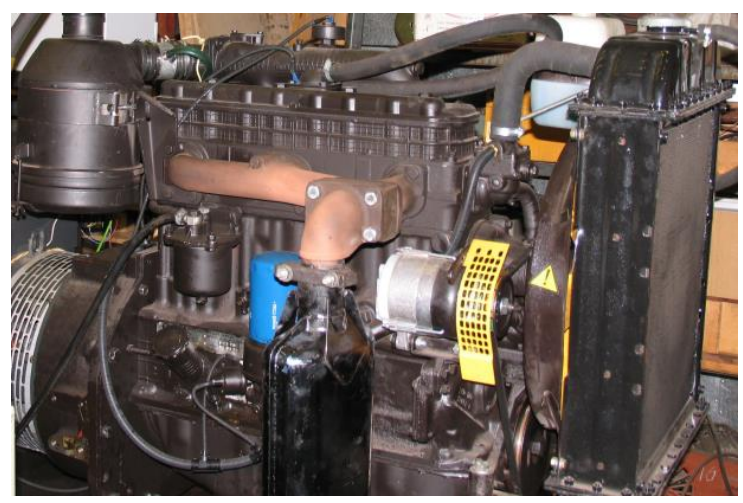

(a)

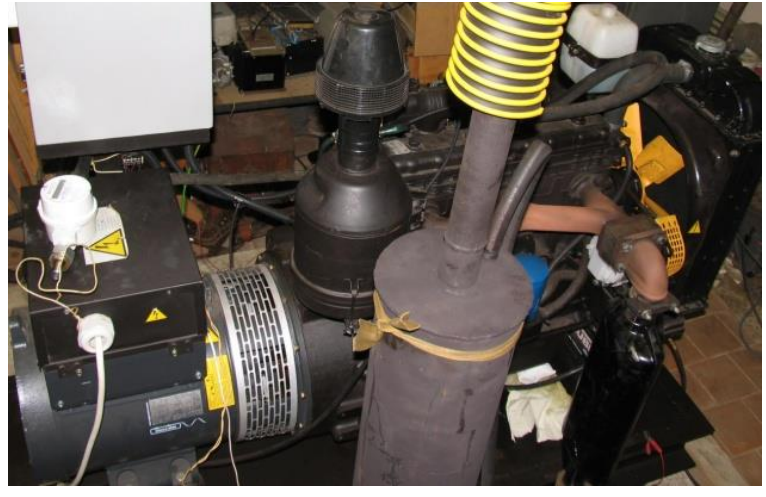

(b)

Figure 1. D-243 diesel engine (a) and diesel-generator set (b). 
Table 1. Structure and operational parameters of D-243 diesel engine.

\begin{tabular}{cc}
\hline Parameters & Value \\
\hline Engine type & Four-stroke, in-line, diesel \\
Number of cylinders & 4 \\
Cylinder diameter $D, \mathrm{~mm}$ & 110 \\
Piston stroke $S, \mathrm{~mm}$ & 125 \\
Total cylinder capacity $i V_{h}, \mathrm{~L}$ & 4.32 \\
Compression ratio $\varepsilon$ & 16.0 \\
Combustion chamber $(\mathrm{CC})$ type, air-fuel mixing & CC of type CNIDI (Central Diesel Engine Research \\
method & Institute), space atomization and film evaporation \\
Nominal speed $n, \mathrm{rpm}$ & 1500 \\
Nominal power $N_{e}, \mathrm{~kW}$ & 36 \\
Fuel supply system type & Separate fuel system \\
High-pressure oil pump & In-line plunger pump Motorpal PP4M10U1f with \\
Diameter of plunger $d_{p l}, \mathrm{~mm}$ & centrifugal governor \\
Plunger stroke $h_{p l}, \mathrm{~mm}$ & 10 \\
Length of high-pressure oil pipe $L_{h}, \mathrm{~mm}$ & 10 \\
Injector & 540 \\
Injector sprayer & Type FDM-22 OJSC “Corapporteur” (Vilnius) \\
Initial injection pressure, $\mathrm{MPa}$ & Motorpal DOP 119S534 with five nozzles of diameter
\end{tabular}

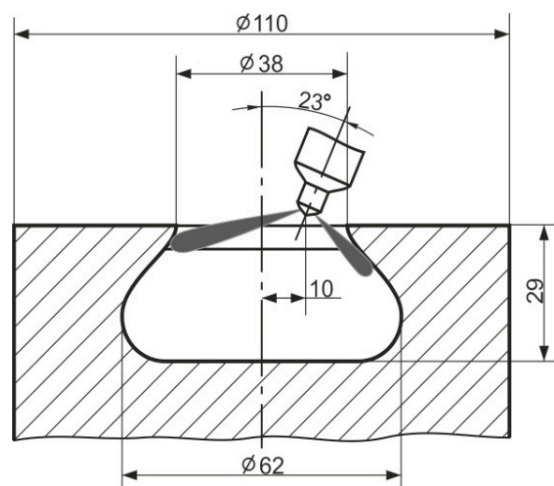

(a)

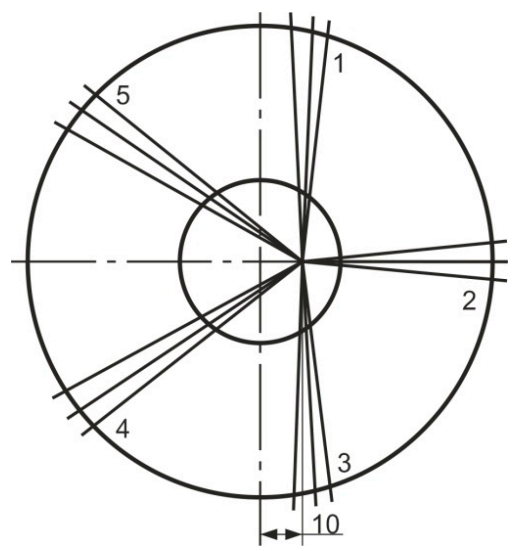

(b)

Figure 2. Combustion chamber of D-243 with injector location scheme (a) and orientation of fuel sprays in combustion chamber (b); 1, 2, 3, 4, 5 are the number of fuel sprays.

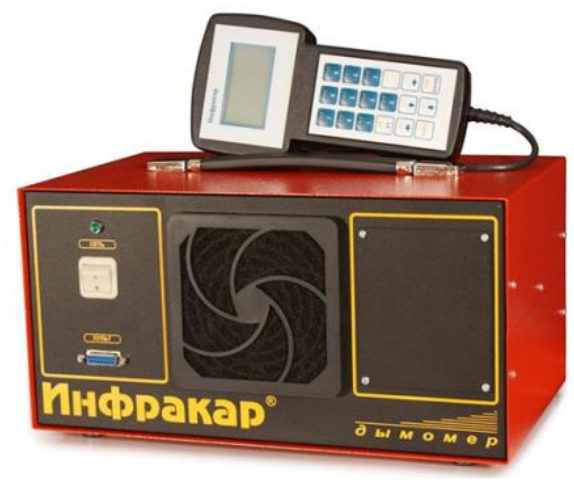

(a)
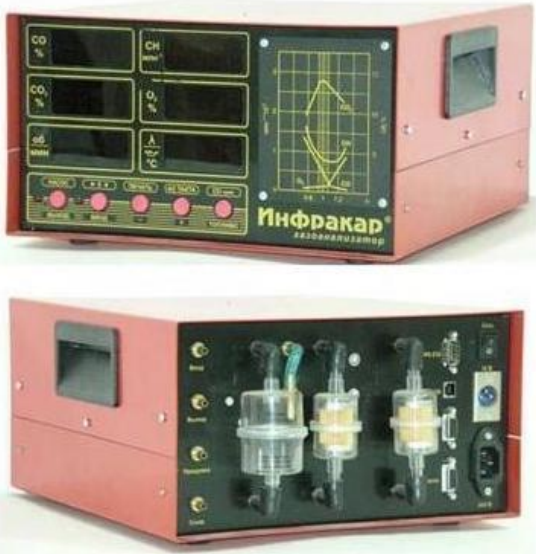

(b)

Figure 3. Smoke meter (a) and exhaust gas analyzer (b). 
Table 2. Main measurement parameters.

\begin{tabular}{cccc}
\hline Measured Parameter & Measuring Range & Accuracy & Uncertainty \\
\hline Engine speed & $0-2500 \mathrm{rpm}$ & $\pm 2.5 \mathrm{rpm}$ & $\pm 0.1 \%$ \\
Engine power & $0-40 \mathrm{~kW}$ & $\pm 0.4 \mathrm{~kW}$ & $\pm 1 \%$ \\
Fuel consumption & $0-12 \mathrm{~kg} / \mathrm{h}$ & $\pm 0.05 \mathrm{~kg} / \mathrm{h}$ & $\pm 0.4 \%$ \\
Air consumption & $0-250 \mathrm{~kg} / \mathrm{h}$ & $\pm 2.5 \mathrm{~kg} / \mathrm{h}$ & $\pm 1 \%$ \\
$\mathrm{O}_{2}$ & $0-21 \mathrm{vol} \%$ & $<3.3 \mathrm{vol} \%: \pm 0.1 \mathrm{vol} \%$ & $\geq 3.3 \mathrm{vol} \%: \pm 3 \mathrm{vol} \%$ \\
$\mathrm{CO}_{2}$ & $0-16 \mathrm{vol} \%$ & $<12.5 \mathrm{vol} \%: \pm 0.5 \mathrm{vol} \%$ & $\geq 12 \mathrm{vol} \%: \pm 4 \mathrm{vol} \%$ \\
$\mathrm{NO}_{\mathrm{x}}$ & $0-4000 \mathrm{ppm}$ & $<1000 \mathrm{ppm}: \pm 100 \mathrm{ppm}$ & $\geq 1000 \mathrm{ppm:} \pm 10 \mathrm{ppm}$ \\
$\mathrm{CO}$ & $0-5 \mathrm{vol} \%$ & $<1 \mathrm{vol} \%: \pm 0.03 \mathrm{vol} \%$ & $\geq 1 \mathrm{vol} \%: \pm 3 \mathrm{vol} \%$ \\
$\mathrm{HC}$ & $0-2000 \mathrm{ppm}$ & $<200 \mathrm{ppm}: \pm 10 \mathrm{ppm}$ & $\geq 200 \mathrm{ppm}: \pm 5 \%$ \\
Exhaust gas smoke & $0-100 \%$ & $\pm 1 \%$ full-scale reading & - \\
\hline
\end{tabular}

It should be noted that DF and CNTs are difficult to mix with each other; we used an UZV-10/150-TN ultrasonic bath based on piezoceramic radiators, which is made by a Russian electrotechnical company (Reltek), to prepare the mixed fuel. This device is designed for ultrasonic cleaning of carbon deposits, fat, and mechanical contaminations from steel parts with various configurations as well as nonferrous metals and nonmetallic materials, including for washing precision parts of diesel fuel supply equipment after their manufacture or repair (Figure 4). After mixing diesel fuel with carbon nanotubes in this bath, a homogeneous, stable mixture with dark brown color was formed (Figure 5).

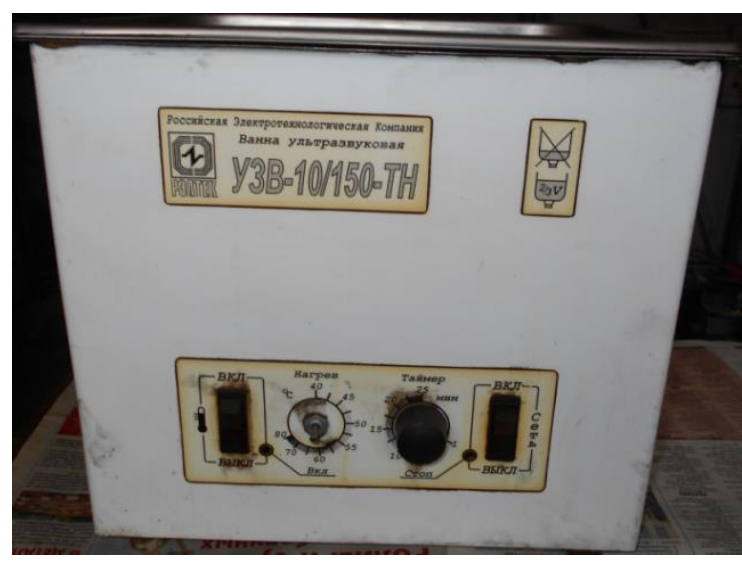

Figure 4. Ultrasonic bath used for preparing mixtures of petroleum diesel fuel with carbon nanotubes (CNTs).

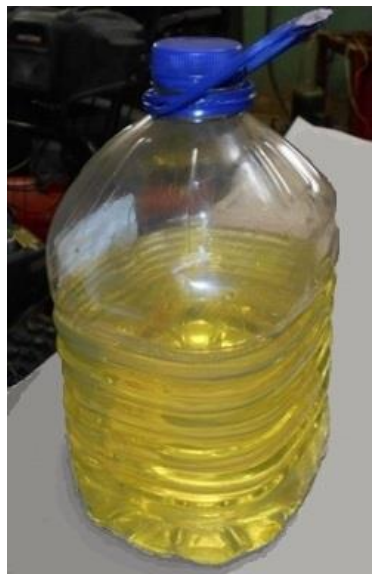

(a)

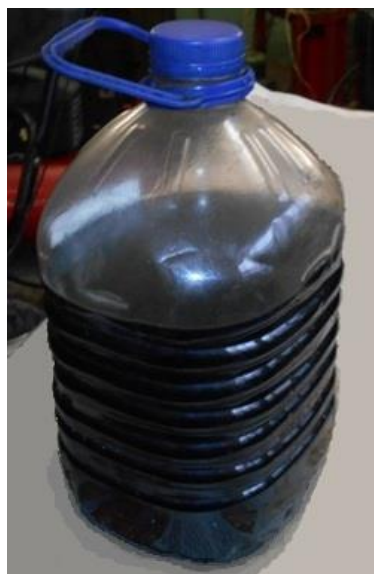

(b)

Figure 5. Initial petroleum diesel fuel (a) and mixture of petroleum diesel fuel with $250 \mathrm{mg} / \mathrm{L}$ of carbon nanotubes prepared in ultrasonic bath $(\mathbf{b})$. 
The dispersion of CNTs into DF was carried out as follows. After the addition of CNTs to petroleum DF during their mixing in the ultrasonic bath, the state of the mixed fuel was continuously monitored. By about the 10th minute of mixing the components, the mixture became almost homogeneous. After this, mixing continued for about $5 \mathrm{~min}$ to ensure complete homogeneity of the mixture. Approximately the same duration of mixing motor fuel with CNTs $(15 \mathrm{~min})$ was realized in [10]. This method of mixing CNTs with motor fuels was also implemented in $[13,14]$. In view of the use of this dispersion method of motor fuels with CNTs in other published works, an analysis of the effect of ultrasonic dispersion on the state of CNTs (on possible defects of CNTs) was not carried out.

In the experiment, the mixed fuel tank was installed directly on the engine stand. During engine operation, the tank was subjected to strong high-frequency vibrations. In this regard, continuous monitoring of the state of the investigated mixed fuels did not reveal the phenomena of CNT deposition in the fuel and their agglomeration.

Because the investigated CNT were similar in size to particles retained by the fine filter of a standard fuel supply system of the tested diesel engine (length of up to $30 \mu \mathrm{m}$ ), the coarse and fine filters were disabled when the engine was tested with mixtures of DF with CNT.

The D-243 diesel engine on the test bench was investigated in maximum regulated speed modes at engine speed $n=1500 \mathrm{rpm}$, which is the standard mode of the studied diesel generator. The current met the requirements for the electric current of industrial networks. The slope of the regulatory characteristic of the diesel $(\delta)$ was $7 \%$, which led to an increase in engine speed from $1480 \mathrm{rpm}$ at full load $\left(N_{e}=36.8 \mathrm{~kW}\right)$ to $1590 \mathrm{rpm}$ at idle $\left(N_{e}=0 \mathrm{~kW}\right)$. During the tests, the static fuel injection advance angle was $13^{\circ} \mathrm{crank}$ angle before the top dead center. As the dose level of CNTs was no more than $500 \mathrm{mg} / \mathrm{L}$ and the mass amount of CNT addition in the blended DF was no more than $0.1 \%$, it could be reasonably assumed that the thermal valve of the blended diesel fuel did not change and equaled $42.5 \mathrm{MJ} / \mathrm{kg}$.

\section{Results and Discussion}

\subsection{Engine Performance: Fuel Consumption, Air Consumption, Air-Fuel Equivalence Ratio, and Brake-Specific Fuel Consumption (BSFC)}

Tests on the diesel engine fueled by petroleum DF with CNT addition were conducted in steady operating conditions. The obtained test results of the D-243 diesel engine running according to the regulatory characteristic are shown in Table 3. They testify that the effect of the addition of CNTs to petroleum DF on fuel consumption was different under different loads. At full load $\left(N_{e}=36.8 \mathrm{~kW}\right.$ at $n=1480 \mathrm{rpm}$ ), a maximum CNT addition of $500 \mathrm{mg} / \mathrm{L}$ led to a minimum reduction in hourly fuel consumption (by only $0.03 \mathrm{~kg} / \mathrm{h}$ or $0.3 \%$ ). At partial loads $\left(N_{e}=23.2 \mathrm{~kW}\right.$ at $n=1510 \mathrm{rpm}$ and $N_{e}=12.3 \mathrm{~kW}$ at $n=1540 \mathrm{rpm}$ ), such an addition of CNTs reduced the hourly fuel consumption by $1.7 \%$ (by $0.12 \mathrm{~kg} / \mathrm{h}$ ) and $2.3 \%(0.11 \mathrm{~kg} / \mathrm{h})$, respectively. At the same time, the amount of CNT addition in petroleum DF had practically no effect on air consumption; it only changed depending on the engine speed. With an increase in the rotational speed from 1480 to $1590 \mathrm{rpm}$ (i.e., 1.074 times), the air consumption increased 1.075-1.08 times. Therefore, the calculated values of the specific effective fuel consumption also differed depending on the load and the amount of CNT addition.

In full load condition, the presence of CNTs in diesel fuel had a weak effect on the BSFC of the investigated diesel engine. However, this effect became more significant under partial load conditions. At the same time, BSFC decreased with the increase in CNT addition. For the blended diesel fuel with $500 \mathrm{mg} / \mathrm{L}$ CNT, the SBFC at loads of $12.3,23.2$, and $36.8 \mathrm{~kW}$ was $372.4,292.2$, and $273.4 \mathrm{~g} / \mathrm{kW} \cdot \mathrm{h}$, respectively. For pure diesel fuel, the SBFC at loads of $12.3,23.2$, and $36.8 \mathrm{~kW}$ was $381.3,297.4$, and $274.2 \mathrm{~g} / \mathrm{kW} \cdot \mathrm{h}$, respectively. Therefore, the addition of $500 \mathrm{mg} / \mathrm{L} \mathrm{CNT} \mathrm{into} \mathrm{petroleum} \mathrm{diesel} \mathrm{fuel} \mathrm{reduced}$ the BSFC by $0.3 \%$ in the full load condition $\left(N_{e}=36.8 \mathrm{~kW}\right)$, which is comparable with the accuracy of its determination, and by $1.8 \%$ at $N_{e}=23.2 \mathrm{~kW}$ and $2.3 \%$ at $N_{e}=12.3 \mathrm{~kW}$ (Figure 6a). This effect can be explained by the fact that multiwalled carbon nanotubes disrupt the uniformity of liquid DF and weaken the intermolecular bonds. This helps to accelerate the process of air-fuel mixture formation by facilitating the decay of the fuel stream, reducing the diameter of droplets, and accelerating their 
heating and evaporation. This leads to a reduction in the ignition delay period and increases brake thermal efficiency. For example, in [19], CNT blends improved BSFC by as much as $19.85 \%$. Moreover, CNTs have high thermal conductivity, which reduces the uneven distribution of the temperature fields in the combustion chamber $[9,17,20]$.

Table 3. Test results of D-243 diesel engine running according to the regulatory characteristic. Engine crankshaft speed $n$, effective power $N_{e}$, hourly fuel consumption $G_{f}$, hourly air consumption $G_{a}$, air-fuel equivalence ratio $\lambda$, brake-specific fuel consumption (BSFC), smoke opacity $K_{X}$.

\begin{tabular}{|c|c|c|c|c|c|c|c|}
\hline \multicolumn{8}{|c|}{ Operation on Petroleum Diesel Fuel } \\
\hline № Mode & $n, \mathrm{rpm}$ & $N_{e}, \mathbf{k W}$ & $G_{f}, \mathrm{~kg} / \mathrm{h}$ & $G_{a}, \mathrm{~kg} / \mathrm{h}$ & $\lambda$ & $\mathrm{BSFC}, \mathrm{g} / \mathrm{kW} \cdot \mathrm{h}$ & $K_{X}, \%$ (Hartridge) \\
\hline 1 & 1480 & 36.8 & 10.09 & 212 & 1.47 & 274.2 & 26.0 \\
\hline 2 & 1510 & 23.2 & 6.90 & 216 & 2.19 & 297.4 & 7.3 \\
\hline 3 & 1540 & 12.3 & 4.69 & 220 & 3.28 & 381.3 & 4.5 \\
\hline 4 & 1590 & 0 & 2.52 & 228 & 6.33 & - & 2.4 \\
\hline \multicolumn{8}{|c|}{ Operation on petroleum diesel fuel mixed with $\mathrm{CNT}$ in the dose level of $125 \mathrm{mg} / \mathrm{L}$} \\
\hline 1 & 1480 & 36.8 & 10.07 & 211 & 1.47 & 273.6 & 17.2 \\
\hline 2 & 1510 & 23.2 & 6.85 & 216 & 2.21 & 295.3 & 6.5 \\
\hline 3 & 1540 & 12.3 & 4.65 & 220 & 3.31 & 378.0 & 4.1 \\
\hline 4 & 1590 & 0 & 2.48 & 228 & 6.43 & - & 2.2 \\
\hline \multicolumn{8}{|c|}{ Operation on petroleum diesel fuel mixed with CNT in the dose level of $250 \mathrm{mg} / \mathrm{L}$} \\
\hline 1 & 1480 & 36.8 & 10.06 & 211 & 1.47 & 273.4 & 13.8 \\
\hline 2 & 1510 & 23.2 & 6.80 & 215 & 2.21 & 293.1 & 6.0 \\
\hline 3 & 1540 & 12.3 & 4.60 & 219 & 3.33 & 374.0 & 3.7 \\
\hline 4 & 1590 & 0 & 2.48 & 227 & 6.40 & - & 2.1 \\
\hline \multicolumn{8}{|c|}{ Operation on petroleum diesel fuel mixed with $\mathrm{CNT}$ in the dose level of $500 \mathrm{mg} / \mathrm{L}$} \\
\hline 1 & 1480 & 36.8 & 10.06 & 210 & 1.46 & 273.4 & 11.2 \\
\hline 2 & 1510 & 23.2 & 6.78 & 214 & 2.21 & 292.2 & 5.6 \\
\hline 3 & 1540 & 12.3 & 4.58 & 219 & 3.34 & 372.4 & 3.4 \\
\hline 4 & 1590 & 0 & 2.46 & 227 & 6.45 & - & 2.0 \\
\hline
\end{tabular}

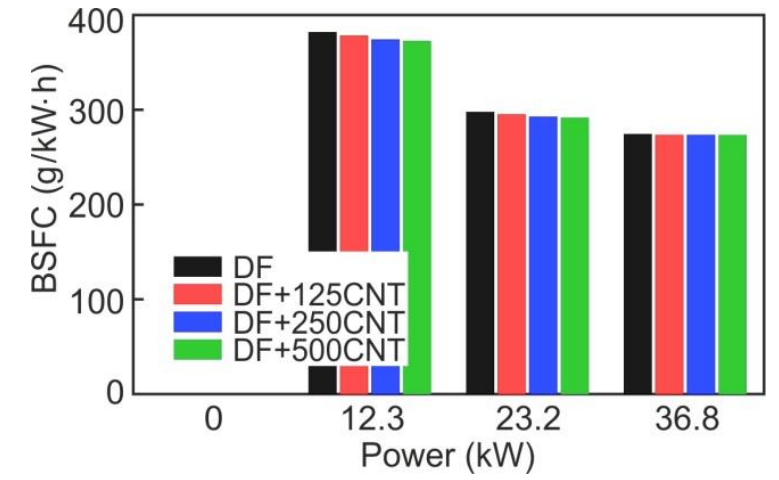

(a)

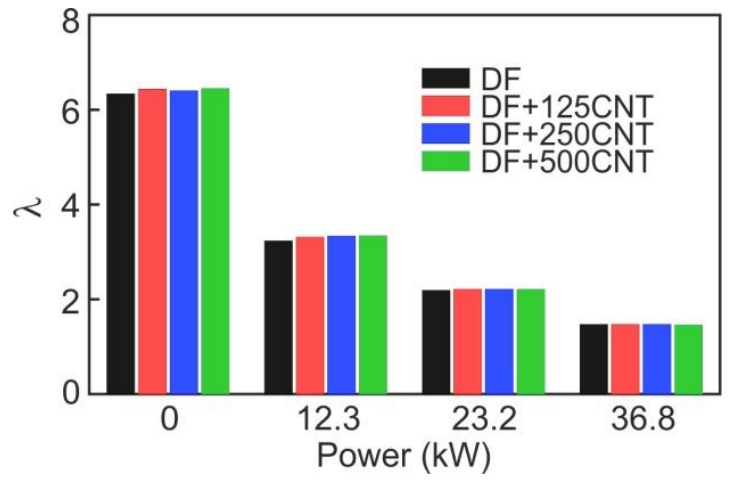

(b)

Figure 6. Change in BSFC (a) and air-fuel equivalence ratio $\lambda(\mathbf{b})$ depending on the amount of CNT addition at different diesel engine loads.

The air-fuel equivalence ratio $\lambda$ of the D-243 diesel engine when operating according to the regulatory characteristic significantly decreased with increasing load (Figure $6 \mathrm{~b}$ ). The minimum values equaled 1.46-1.47. The dose level of CNTs had practically no effect on it. 
3.2. Exhaust Gas Emission Measurements: Carbon Monoxide, Carbon Dioxide, Hydrocarbon, Nitrogen Oxides, and Smoke

The obtained exhaust gas emission results of the D-243 diesel engine when operating according to the regulatory characteristic are shown in Table 4 . They indicate the different effects of the diesel engine load and CNT addition in petroleum DF on individual emission parameters (indicators). The obtained experimental data on the emission performance of the investigated diesel engine showed that the addition of CNTs to petroleum DF had little effect on CO and light unburned HC emissions.

Table 4. The results of exhaust gas emission of the D-243 diesel engine when operating according to the regulatory characteristic. Engine crankshaft speed $n$, effective power $N_{e}$, volume concentration of oxygen in exhaust gas $\mathrm{C}_{\mathrm{O}_{2}}$, carbon dioxide emission $\mathrm{C}_{\mathrm{CO}_{2}}$, nitrogen oxides emission $\mathrm{C}_{\mathrm{NO}_{\mathrm{x}}}$, carbon monoxide emission $C_{\mathrm{CO}}$, and hydrocarbon emission $C_{\mathrm{HC}}$.

\begin{tabular}{|c|c|c|c|c|c|c|c|}
\hline \multicolumn{8}{|c|}{ Operation on Petroleum Diesel Fuel } \\
\hline № Mode & $n, \mathrm{rpm}$ & $N_{e}, \mathbf{k W}$ & $C_{\mathrm{O}_{2}}, \%$ & $C_{\mathrm{CO}_{2}}, \%$ & $C_{\mathrm{NO}_{\mathrm{x}}}, \mathrm{ppm}$ & $C_{\mathrm{CO}}, \%$ & $C_{\mathrm{HC}}, \mathrm{ppm}$ \\
\hline 1 & 1480 & 36.8 & 7.74 & 9.59 & 1763 & 0.013 & 9 \\
\hline 2 & 1510 & 23.2 & 12.47 & 5.96 & 1270 & 0.014 & 9 \\
\hline 3 & 1540 & 12.3 & 15.67 & 3.73 & 612 & 0.015 & 10 \\
\hline 4 & 1590 & 0 & 18.31 & 1.80 & 189 & 0.020 & 10 \\
\hline \multicolumn{8}{|c|}{ Operation on petroleum diesel fuel mixed with CNT at the dose level of $125 \mathrm{mg} / \mathrm{L}$} \\
\hline 1 & 1480 & 36.8 & 7.80 & 9.58 & 1697 & 0.013 & 10 \\
\hline 2 & 1510 & 23.2 & 12.63 & 5.74 & 1230 & 0.013 & 10 \\
\hline 3 & 1540 & 12.3 & 15.70 & 3.60 & 585 & 0.014 & 10 \\
\hline 4 & 1590 & 0 & 18.33 & 1.78 & 184 & 0.015 & 9 \\
\hline \multicolumn{8}{|c|}{ Operation on petroleum diesel fuel mixed with CNT at the dose level of $250 \mathrm{mg} / \mathrm{L}$} \\
\hline 1 & 1480 & 36.8 & 7.88 & 9.55 & 1678 & 0.014 & 10 \\
\hline 2 & 1510 & 23.2 & 12.70 & 5.65 & 1220 & 0.014 & 10 \\
\hline 3 & 1540 & 12.3 & 15.72 & 3.54 & 580 & 0.014 & 11 \\
\hline 4 & 1590 & 0 & 18.34 & 1.76 & 178 & 0.015 & 10 \\
\hline \multicolumn{8}{|c|}{ Operation on petroleum diesel fuel mixed with CNT in the dose level of $500 \mathrm{mg} / \mathrm{L}$} \\
\hline 1 & 1480 & 36.8 & 7.90 & 9.50 & 1670 & 0.013 & 10 \\
\hline 2 & 1510 & 23.2 & 12.83 & 5.65 & 1205 & 0.013 & 10 \\
\hline 3 & 1540 & 12.3 & 15.72 & 3.23 & 575 & 0.014 & 10 \\
\hline 4 & 1590 & 0 & 18.34 & 1.72 & 174 & 0.015 & 11 \\
\hline
\end{tabular}

At the same time, there was a tendency of $\mathrm{CO}$ emission reduction when CNTs were used (Figure 7). It is known that $\mathrm{CO}$ emission decreases with the increase in engine load [21]. This is due to the increased reaction rate of the oxidation of carbon monoxide with an increase in the combustion temperature, which increases with the increase in fuel injection quantity. However, $\mathrm{CO}$ emission may increase in full load conditions due to the dissociation of carbon dioxide in the high-temperature zones of the combustion chamber. Under partial load conditions, the high catalytic activity of nanoparticles contributes to the reduction in CO emission. In large load conditions, using CNT increases the carbon content in the air-fuel mixture, and the small excess air coefficient reduces the efficiency of carbon oxidation, which creates conditions for the formation of carbon monoxide. In general, the results obtained for carbon monoxide emissions were at the level of measurement error (Table 2).

As for the light unburned HC emission, it should be noted that the emission of this toxic component in exhaust gases of the studied diesel engine was very low (Figure 8). They were at the level of measurement error (Table 2). This indicates a fairly complete combustion of fuel. Therefore, the emissions of light unburned $\mathrm{HC}$ from the exhaust gas of the investigated diesel engine were weakly dependent on the dose level of CNTs in petroleum DF. 


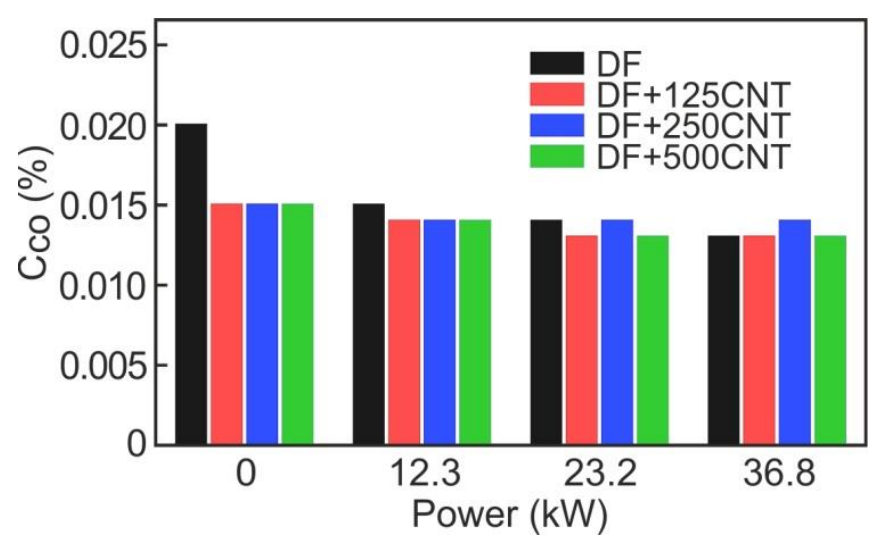

Figure 7. Change in carbon monoxide $\left(C_{C O}\right)$ in exhaust gas depending on the amount of $C N T$ addition at different diesel engine loads.

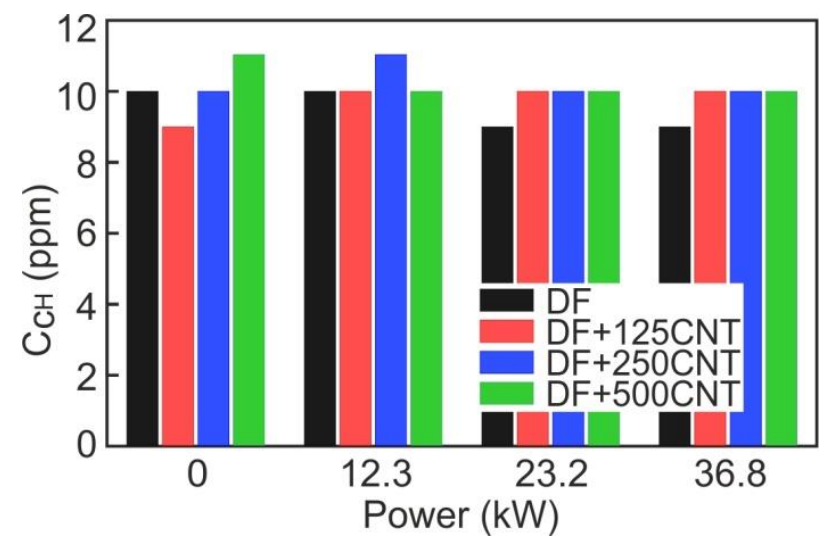

Figure 8. Change in hydrocarbon $\left(C_{H C}\right)$ in exhaust gas depending on the amount of CNT addition at different diesel engine loads.

An increase in diesel load unambiguously led to a significant increase in carbon dioxide emissions (Figure 9). This was due to an increase in the amount of fuel supplied in the cylinder and a corresponding decrease in the air-fuel equivalence ratio (Figure 6b). In this case, the effect of the amount of CNT addition had practically no effect. The change in carbon dioxide emission depending on CNT addition was less than the measurement error (Table 2).

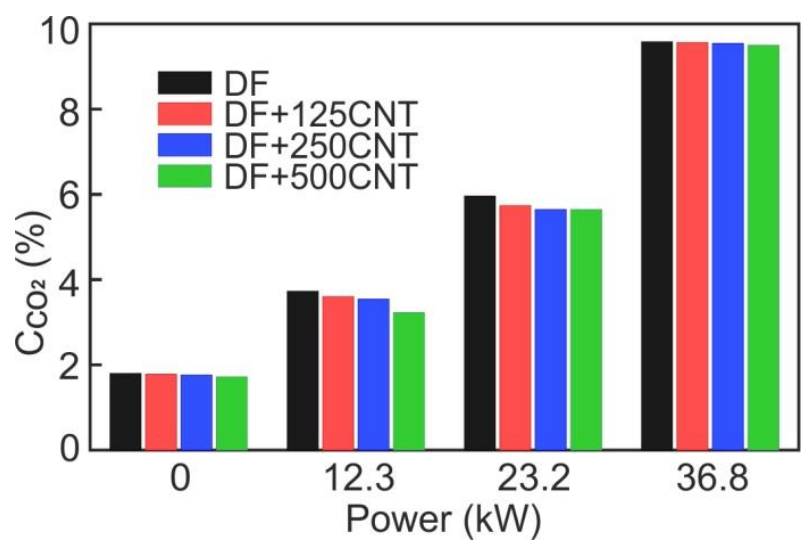

Figure 9. Change in carbon dioxide $\left(\mathrm{C}_{\mathrm{CO}_{2}}\right)$ in exhaust gas depending on the amount of CNT addition at different diesel engine loads. 
An increase in load on the diesel engine operating according to the regulatory characteristic also led to a significant increase in exhaust smoke (Figure 10). When the engine was idling, the exhaust smoke had the smallest values of no more than 2.5\% (Table 3 and Figure 10). As the load increased, the exhaust smoke increased and reached $26 \%$. The use of CNT additives in petroleum diesel fuel significantly affected the exhaust smoke (Figure 10).

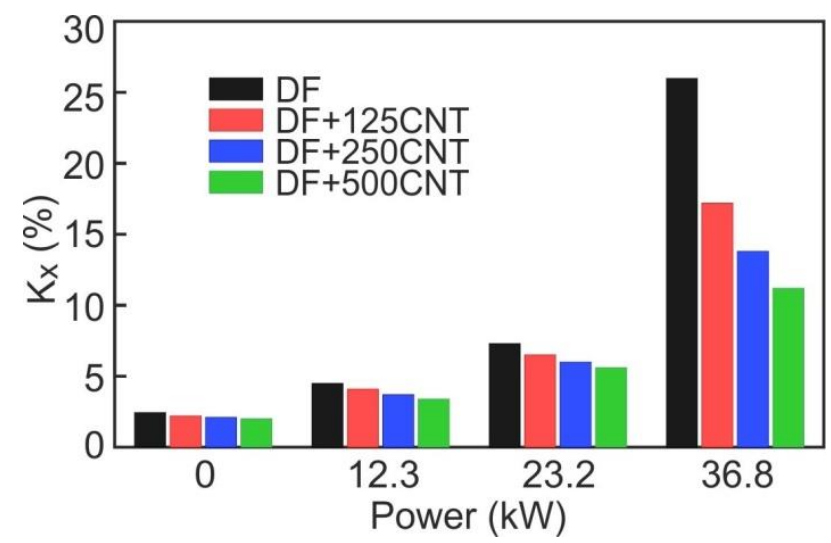

Figure 10. Change in exhaust smoke depending on the amount of CNT addition at different diesel engine loads.

An increase in CNT content in petroleum DF was accompanied by a decrease in the exhaust smoke opacity. The maximum reduction in the exhaust smoke opacity was achieved in the full load condition $\left(N_{e}=36.8 \mathrm{~kW}\right)$ with engine speed of $1480 \mathrm{rpm}$ and CNT content in petroleum DF of $500 \mathrm{mg} / \mathrm{L}$. In this case, the exhaust smoke opacity decreased from $26.0 \%$ to $11.2 \%$ on the Hartridge scale, that is, by $57 \%$ (Figure 11). This significantly exceeded the measurement error of exhaust gas smoke (Table 2). Such a decrease in the exhaust smoke opacity as well as specific effective fuel consumption can be explained by the fact that the presence of multiwalled carbon nanotubes in petroleum diesel fuel improves the quality of mixture formation and combustion by facilitating the decay of the fuel spray, reducing the diameter of the droplets, and accelerating their heating and evaporation. As is known, this leads to a reduction in the ignition delay period and the duration of combustion [13,22,23]. This has a favorable effect on the exhaust smoke. Therefore, from the point of view of reducing exhaust smoke, a further increase in the proportion of CNTs in petroleum diesel fuel is promising.

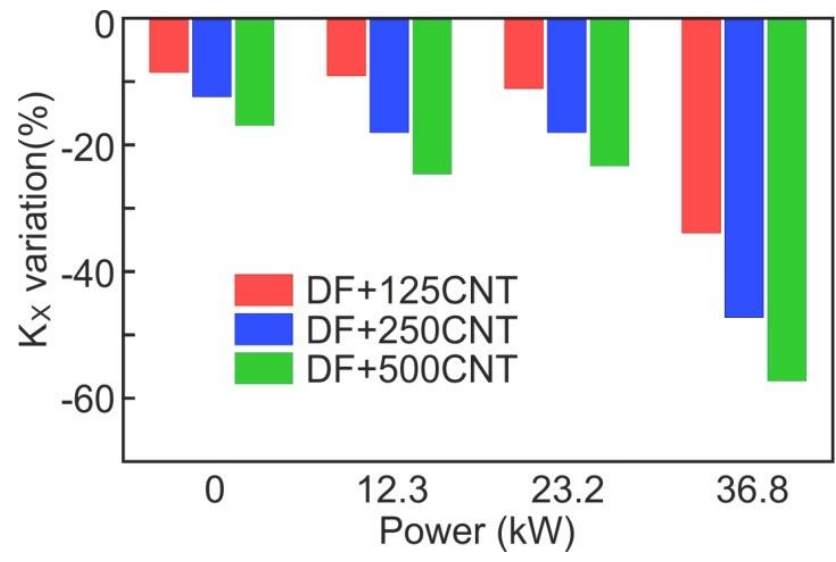

Figure 11. Relative change in exhaust smoke opacity for CNT-blended diesel fuel compared with exhaust smoke opacity for pure petroleum diesel fuel (the exhaust smoke opacity for the diesel engine fueled with pure petroleum DF was taken as the basic smoke opacity value). 
An increase in load on the diesel engine working on a regulatory characteristic also led to an increase in nitrogen oxide emissions (Figure 12). When the diesel engine was idling, the $\mathrm{NO}_{\mathrm{x}}$ emissions was the lowest, with no more than $200 \mathrm{ppm}$ (Table 4 and Figure 12). This was twice the measurement error of nitrogen oxides (Table 2). As the load increased, nitrogen oxide emissions increased and exceeded $1700 \mathrm{ppm}$. The use of CNT additives in petroleum diesel fuel significantly reduced nitrogen oxide emissions (Figure 13).

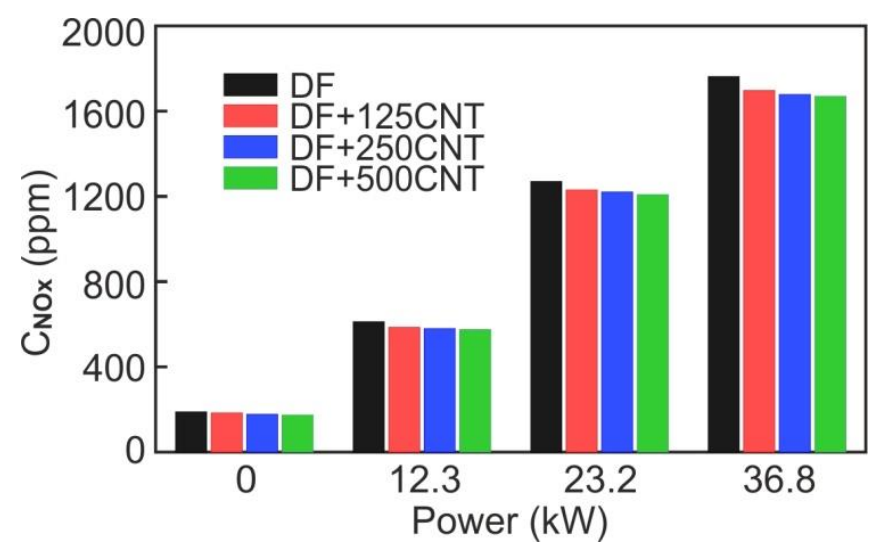

Figure 12. Change in nitrogen oxides $\left(C_{\mathrm{NO}_{\mathrm{x}}}\right)$ in exhaust gas depending on the amount of $\mathrm{CNT}$ addition at different diesel engine loads.

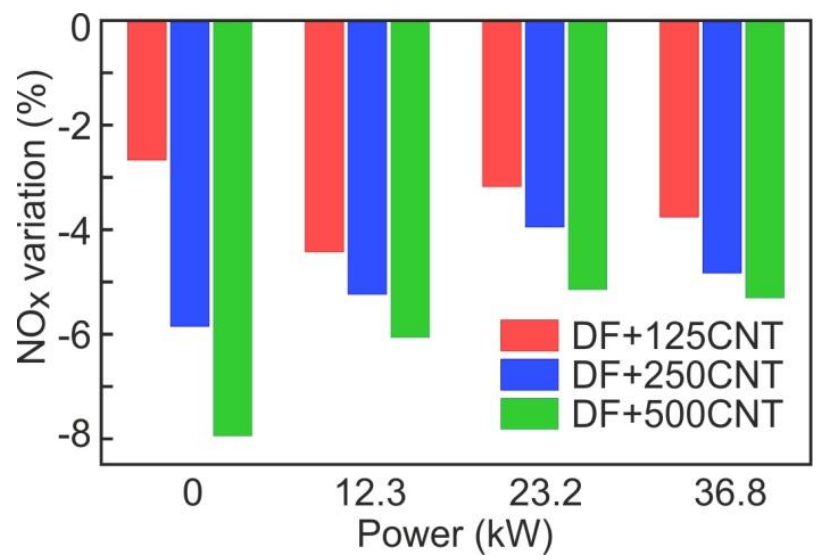

Figure 13. Relative change in $\mathrm{NO}_{x}$ emission for CNT-blended diesel fuel compared with $\mathrm{NO}_{\mathrm{x}}$ emission for pure petroleum diesel fuel (the $\mathrm{NO}_{\mathrm{x}}$ content in exhaust gas for diesel engine fueled with pure petroleum $\mathrm{DF}$ was taken as the basic $\mathrm{NO}_{\mathrm{x}}$ emission value).

Along with the different operating conditions of the diesel engine, the relative change in the $\mathrm{NO}_{\mathrm{x}}$ content in exhaust gas ranged from $2.5 \%$ to $8.0 \%$. In the nominal operating mode $(n=1480 \mathrm{rpm}$, $N_{e}=36.8 \mathrm{~kW}$ ), an increase in the amount of CNT addition in petroleum DF from 0 to $500 \mathrm{mg} / \mathrm{L}$ led to a decrease in the content of nitrogen oxides in the exhaust gas from 1763 to $1670 \mathrm{ppm}$, i.e. by $5.3 \%$. Similar results are given in [19], in which CNT blends led to an overall improvement in $\mathrm{NO}_{\mathrm{x}}$ emissions by $4.48 \%$. As noted earlier, this is a consequence of improving the quality of mixture formation and combustion. As a result, a decrease in combustion temperature and a reduction in combustion duration are achieved, which leads to a decrease in the $\mathrm{NO}_{\mathrm{x}}$ emission [23-26].

\section{Conclusions}

In conclusion, we noted a good correlation of the obtained experimental results with the aforementioned experimental data from other authors as well as data published in [19,27-29]. 
Overall, the obtained experimental results show that the addition of carbon nanotubes to petroleum diesel fuel can be considered as an effective means of improving the emission performance of transport diesel engines. The addition of CNTs was found to have the greatest effect on smoke opacity. In nominal operating conditions, an increase in the amount of CNT addition in petroleum DF from 0 to $500 \mathrm{mg} / \mathrm{L}$ was accompanied by a decrease in exhaust smoke opacity from $26.0 \%$ to $11.2 \%$ on the Hartridge scale, i.e., more than a two-fold decrease. At the same time, there was a decrease in $\mathrm{NO}_{\mathrm{x}}$ emission from 1763 to $1670 \mathrm{ppm}$, i.e. by $5.3 \%$. The addition of CNTs to petroleum DF had little effect on CO and $\mathrm{HC}$ emissions; there was a slight tendency toward a decrease in $\mathrm{CO}$ emission, but the change in $\mathrm{HC}$ emission of the studied diesel engine was insignificant.

Author Contributions: V.M. conceived the concept, designed the methodology, administrated the project, and wrote the original draft of this paper. V.K. contributed to formal analysis and validation of the results and wrote the original draft of this paper. A.Z. contributed to formal analysis of the results, provided supervision for research execution, and edited the draft paper. V.F. provided funding acquisition, designed the methodology, and contributed to validation of the results. B.S. provided funding acquisition and resources, performed the experiment, and processed the results. V.N. performed the experiment and processed the results.

Funding: This research received no external funding.

Conflicts of Interest: The authors declare no conflict of interest.

\section{References}

1. Aleksandrov, A.A.; Arkharov, I.A.; Bagrov, V.V.; Gaivoronskii, A.I.; Grekhov, L.V.; Devianin, S.N.; Ivashchenko, N.A.; Markov, V.A. Alternative Fuels for Internal Combustion Engines; LLC NITS “Inzhener" Publ., LLC “Oniko-M.” Publ.: Moscow, Russia, 2012.

2. Shatrov, M.G.; Khachiyan, A.S.; Golubkov, L.N.; Dunin, A.Y. Improvement of Working Processes of Automotive Diesel Engines and their Fuel Systems Running on Alternative Fuels; MADI: Moscow, Russia, 2012.

3. Vasiliev, I.P. Effect of Vegetable Fuels on the Ecological and Economic Indicators of Diesel; V. Dahl EUNU: Lugansk, Russia, 2009.

4. Lotko, W.; Lukanin, V.N.; Khatchiyan, A.S. Usage of Alternative Fuels in Internal Combustion Engines; MADI: Moscow, Russia, 2000.

5. Arkharov, I.; Markov, V.; Bagrov, V.; Devyanin, S.; Ksenofontov, B.; Neverova, V.; Sereda, A.; Sharin, E.; Zykov, S.; Sa, B. Petroleum Motor Fuels: Ecological Aspects of Application; LLC NITS “Inzhener" Publ.: Moscow, Russia, 2019.

6. Markov, V.A.; Devyanin, S.N.; Semenov, V.G.; Bagrov, V.V.; Zykov, S.A. Motor Fuels Manufactured from Vegetable Oils; Lambert Academic Publishing: Riga, Latvia, 2019.

7. Wang, X.; Xu, X.; Choi, S.U.S. Thermal Conductivity of Nanoparticle-Fluid Mixture. J. Thermophys. Heat Transf. 1999, 13, 474-480. [CrossRef]

8. Choi, S.U.S. Nanofluids: From Vision to Reality Through Research. J. Heat Trans. 2009, 131, $033106-033115$. [CrossRef]

9. Naddaf, A.; Heris, S.Z. Density and Rheological Properties of Different Nanofluids Based on Diesel Oil at Different Mass Concentrations. An experimental study. J. Thermal Anal. Calorim. 2019, 135, 1229-1242. [CrossRef]

10. Heydari-Maleney, K.; Taghizadeh-Alisaraei, A.; Ghobadian, B.; Abbaszadeh-Mayvan, A. Analyzing and Evaluation of Carbon Nanotubes Additives to Diesohol-B2 Fuels on Performance and Emission of Diesel Engines. Fuel 2017, 196, 110-123. [CrossRef]

11. Gardy, J.; Nourafkan, E.; Osatiashtiani, A.; Lee, A.F.; Wilson, K.; Hassanpour, A.; Lai, X. A core-shell SO4/Mg-Al-Fe3O4 catalyst for biodiesel production. Appl. Catal. B Environ. 2019, 259, 118093. [CrossRef]

12. Gardy, J.; Rehan, M.; Hassanpour, A.; Lai, X.; Nizami, A.-S. Advances in nano-catalysts based biodiesel production from non-food feedstocks. J. Environ. Manag. 2019, 249, 109316. [CrossRef]

13. Sadhik Basha, J.; Anand, R.B. Performance, Emission and Combustion Characteristics of a Diesel Engine using Carbon Nanotubes Blended Jatropha Methyl Ester Emulsions. Alex. Eng. J. 2014, 53, 259-273. [CrossRef]

14. Balaji, G.; Cheralathan, M. Effect of CNT as Additive with Biodiesel on the Performance and Emission Characteristics of a DI Diesel Engine. Int. J. ChemTech Res. 2015, 7, 1230-1236. 
15. El-Seesy, A.I.; Abdel-Rahman, A.K.; Bady, M.; Ookawara, S. Performance, Combustion and Emission Characteristics of a Diesel Engine Fueled by Biodiesel-Diesel Mixtures with Multi-Walled Carbon Nanotubes Additives. Energy Convers. Manag. 2017, 135, 373-393. [CrossRef]

16. Sadhik Basha, J.; Anand, R.B. An Experimental Investigation in a Diesel Engine Using Carbon Nanotubes Blended Water-Diesel Emulsion Fuel. Proc. Inst. Mech. Eng. Part A J. Power Energy 2011, 225, 279-288. [CrossRef]

17. Chengdu Organic Chemicals Co. Ltd. Chinese Academy of Sciences: Industrial Multi-wall Carbon Nanotubes. Available online: http://www.timesnano.com/en/view.php?prt=3,30,87,187 (accessed on 15 October 2019).

18. Sadhik Basha, J.; Anand, R.B. Role of nanoadditive blended biodiesel emulsion fuel on the working charcteristics of a diesel engine. J. Renew. Sustain. Energy 2011, 3, 023106. [CrossRef]

19. Chen, A.F.; Adzmi, M.A.; Adam, A.; Othman, M.F.; Kamaruzzaman, M.K.; Mrwan, A.G. Combustion Characteristics, Engine Performances and Emissions of a Diesel Engine Using Nanoparticle-Diesel Fuel Blends with Aluminium Oxide, Carbon Nanotubes and Silicon Oxide. Energy Convers. Manag. 2018, 171, 461-477. [CrossRef]

20. Liu, M.S.; Lin, M.C.C.; Huang, I.T.; Wang, C.C. Enhancement of Thermal Conductivity with Carbon Nanotube for Nanofluids. Int. Commun. Heat Mass Transf. 2005, 32, 1202-1210. [CrossRef]

21. Hosseini, S.H.; Taghizadeh-Alisaraei, A.; Ghobadian, B.; Abbaszadeh-Mayvan, A. Performance and Emission Characteristics of a CI Engine Fuelled with Carbon Nanotubes and Diesel-Biodiesel Blends. Renew. Energy 2017, 111, 201-213. [CrossRef]

22. El-Seesy, A.I.; Hamdy Hassan, H. Investigation of the Effect of Adding Graphene oxide, Grapheme Nanoplatelet, and Multiwalled Carbon Nanotube Additives with n-Butanol-Jatropha Methyl Ester on a Diesel Engine Performance. Renew. Energy 2019, 132, 558-574. [CrossRef]

23. Karthikeyan, S.; Prathima, A. Emission Analysis of the Effect of Doped Nano-Additives on Biofuel in a Diesel Engine. Energy Sources Part A Recov. Utiliz. Environ. Eff. 2016, 38, 3702-3708. [CrossRef]

24. Selvan, V.A.M.; Anand, R.B.; Udayakumar, M. Effect of Cerium Oxide Nanoparticles and Carbon Nanotubes as Fuel-Borne Additives in Diesterol Blends on the Performance, Combustion and Emission Characteristics of a Variable Compression Ratio Engine. Fuel 2014, 130, 160-167. [CrossRef]

25. Naddaf, A.; Heris, S.Z. Experimental Study on Thermal Conductivity and Electrical Conductivity of Diesel Oil-Based Nanofluids of Graphene Nanoplatelets and Carbon Nanotubes. Int. Commun. Heat Mass Transf. 2018, 95, 116-122. [CrossRef]

26. Ooi, J.B.; Ismail, H.M.; Tan, B.T.; Wang, X. Effects of Graphite Oxide and Single-Walled Carbon Nanotubes as Diesel Additives on the Performance, Combustion, and Emission Characteristics of a Light-Duty Diesel Engine. Energy 2018, 161, 70-80. [CrossRef]

27. Markov, V.A.; Bashirov, R.M.; Gabitov, I.I. Toxicity of Diesel Engines Exhaust Gases; BMSTU Publ.: Moscow, Russia, 2002.

28. Praveen, A.; Narayana Rao, G.L.N.; Balakrishna, B. The Combined Effect of Multiwalled Carbon Nanotubes and Exhaust Gas Recirculation on the Performance and Emission Characteristics of a Diesel Engine. Int. J. Ambient Energy 2018, 40, 791-799. [CrossRef]

29. Velumani, V.; Lawrence, P.; Sivaprakasam, S. Performance and Emission Analysis on DI Diesel Engine with Multi-walled Carbon Nanotubes. Int. J. Appl. Eng. Res. 2018, 13, 16697-16700.

(C) 2019 by the authors. Licensee MDPI, Basel, Switzerland. This article is an open access article distributed under the terms and conditions of the Creative Commons Attribution (CC BY) license (http://creativecommons.org/licenses/by/4.0/). 